UDC 82-311.3

DOI: https://doi.org/10.18524/2307-4604.2019.1(42).168918

\title{
THE GREEK FOLK TALE: TYPOLOGY AND ANALYSIS Podkovyroff N.
}

lecturer, Odessa National I.I. Mechnikov University

The article outlines typology of the Greek folk tale, its structure and plot peculiarities. The folk tale is a reproduction of thoughts and beliefs and every reader experiences the folk tale in a different way according to his or her experiences. Therefore, the folk tale is not just a remnant of the past, but a collection of cultural elements which are gradually put together by the narrators and which reach the readers or listeners as a cultural blend that they need to decode. The Greek folk tales have been known since ancient times. Herodotus includes folk tales in his Histories, while Aristophanes mentions a story-teller named Philepsios. Moreover, Aristotle states the fact that children's education includes listening to fables and folk tales. Later professional storytellers appear in the Greek society. During the Byzantine period there are very few references to folk tales and the only thing we can mention is that there were mime artists who used to entertain the rulers and lords with their narrations. During the period of Ottoman empire in Greece, the folk tale and other forms of folk culture became the main expression of social reality. The storytellers of that time contributed to the preservation and development of folk oral tradition and, as a result, folk tales were told by sailors, shepherds, they were heard during the long trips of caravans, and they were also very common in agricultural life.

Key words: folk tale, understanding of life, Greek society, analysis.

\section{ГРЕЦЬКА НАРОДНА КАЗКА: ТИПОЛОГІЯ І АНАЛІЗ Подковирофрф $\mathrm{H}$. \\ викладач, Одеський національний університет імені І.І. Мечникова}

У статті висвітлено типологію грецької народної казки, ї структуру та сюжетні особливості. Народна казка є відтворенням думок і вірувань, і кожен читач переживає народну казку по-іншому відповідно до свого досвіду. Таким чином, народна казка - це не просто залишок минулого, а колекція культурних елементів, які поступово об'єднуються оповідачами і досягають читачів або слухачів як культурна суміш, яку їм потрібно розшифррувати. Грецькі народні казки відомі з давніх часів. У свої Історії Геродот включає народні казки, а Арістофран згадує оповідача Філепсіоса. Більше того, Аристотель стверджує, що освіта дітей включає слухання байок і народних казок. Пізніше в грецькому суспільстві з'являються профресійні оповідачі. У візантійський період дуже мало посилань на народні казки, і єдине, про що ми можемо згадати - це були мімісти, які розважали правителів і панів своїми оповіданнями. У період Османської імперії в Греції народна казка та інші форми народної культури стали основним виразом соціальної реальності. Оповідачі того часу сприяли збереженню і розвитку народної усної традиції, $i$, як наслідок, народні казки розповідали матроси, пастухи, їх чули під час тривалих поїздок караванів, і вони також були дуже поширені в сільському житті.

Ключові слова: народна казка, розуміння життя, грецьке суспільство, аналіз

\section{ГРЕЧЕСКАЯ НАРОДНАЯ СКАЗКА: ТИПОЛОГИЯ И АНАЛИЗ. Подковыроффф $\mathrm{H}$.}

преподаватель, Одесский национальный университет имени И.И. Мечникова

В статье освещена типология греческой народной сказки, ее структура и сюжетные особенности. Народная сказка является воспроизведением мыслей и верований, и каждый читатель переживает народную сказку по-другому согласно своему опыту. Таким 
образом, народная сказка - это не просто остаток прошлого, а коллекция культурных элементов, которые постепенно объединяются рассказчиками и достигают читателей или слушателей как культурная смесь, которую им нужно расшифровать. Греческие народные сказки известны с давних времен. В свои Істории Геродот включает народные сказки, а Аристофран вспоминает рассказчика Филепсиоса. Более того, Аристотель утверждает, что образование детей включает слушания басен и народных сказок. Позже в греческом обществе появляются профрессиональные рассказчики. В византийский период очень мало ссылок на народные сказки, и единственное, о чем мы можем упомянуть - это мимы, которые развлекали правителей и господ своими рассказами. В период Османской империи в Греции народная сказка и другие фрормы народной культуры стали основным выражением социальной реальности. Рассказчики того времени способствовали сохранению и развитию народной устной традиции, и, как следствие, народные сказки рассказывали матросы, пастухи, их слышали во время длительных поездок караванов, и они также были очень распространены в сельской жизни.

Ключевые слова: народная сказка, понимание жизни, греческое общество, анализ.

\section{Introduction}

The study of folk tales introduces us to the long-term time scale (Braudel 1969), since the time of today originates in yesterday and the past. At a time when folk narrators are becoming rare due to the technological and cultural evolution and also due to the new living conditions and the decline of agricultural and pastoral life, we will try to present the Greek folk tale as part of the heritage of a culture that still has a lot to offer to scholars, scientists and everyday readers, whether they read it in Greek or translated into other languages.

The Greek folk tales that flourished during the $17^{\text {th }}, 18^{\text {th }}$ and $19^{\text {th }}$ century were told by "paramithades" (storytellers) who were often uneducated people but they had a special talent for narrating stories and their stories sometimes lasted for a few days. The first storytellers were bakers and after their work they used to gather their listeners around their warm oven. Moreover, old men used to tell folk tales to fishermen who were going fishing for a few days. Those stories were often naughty. In earlier times there were also storytellers who went to palaces and mansions to narrate the Homeric Epics. Despite their folk origin, however, the tales have a well-thought structure. The folk tales are given their titles by the storytellers themselves or by the people or they are sometimes named after the person who tells them.

The aim of the paper is to outline typology of the Greek folk tale, its structure and plot peculiarities.

\section{Results and discussion}

The etymology of "paramythi", the Greek word for folk tale, helps us understand the folk tale itself. "Paramythi" is an ancient Greek word and it consists of the word "para" (beside, related to) and the word "mythos" (myth). This means that the folk tale is closely related to a myth but it is not a myth itself. The function of the folk tale is not a matter of its grammar but it is a matter of its semantics and its meaning. The word "paramythi" itself helps us understand that the folk tale has a deeper common meaning and it allows us to escape our problems and to move away from reality into a mythical world.

The folk tale has a typical beginning:

- Mia fora ki enan kairo... (Once upon a time...) This means that the folk tale is timeless; it does not have an exact date. 
- Kokkini klosti demeni dos tis batso na gyrisei paramythi n'arxinisei.... (Tied red thread, give it a kick to make it turn and start the tale...) This poem which is a folk creation provides us with a connection between everyday life and the fairytale world.

- Mia fora ki enan kairo itan ... (Once upon a time there was...) The past tense of the verb shows that the events that will take place have already happened at an indefinite time in the past that we cannot specify.

The ending is also typical:

- Ezisan autoi kala, ki emeis kalytera (They lived happily ever after, just like us) This sentence is a bridge between the present and the future.

- Oute emeis imastan, oute eseis.....(Neither I nor you were there)

The roots of the folk tale can be found in:

1. Greek mythology, for example the epic of Odyssey, the myth of Athena and Arachne etc.

2. Religion, especially the New Testament.

3. In very few cases the Greek folk tale has a place name. So, the same tales and the same collections are told in many places in their own languages. However, we can understand their origin based on some details, for example a reference to oranges as precious fruits shows that a place does not have enough water.

4. All folk tales make reference to elements of the long history of the Greek people.

In Greek folk tales we often find common patterns, for example common episodes with witches and dragons. So the folk tale is a collection of motifs and patterns that are connected in various ways, but the structure of the tale is essentially free.

Of course the origin of the folk tale is

- Indo-European, since folk tales come from the myths of Arion that later travelled to Asia and Europe.

- Indian origin.

- Multi-genetic origin, with similar symbols of human life and common situations that give rise to similar folk tales.

- There are common cores everywhere, which spread from place to place after the first big tale was born.

In the content of the folk tale we can find:

- The development of cosmological myths.

- Allegories of old religious beliefs.

- Dreams that specific people have, for example priests who interpret their dreams as messages.

- Memories of life in the past.

- Moreover folk tales are being enriched, as each society finds old tales and enriches them with its own experiences.

Folk tales can be put into the following categories:

- Magical, mythical: fairytales with elves, winged horses, animals and witches

- Narrative, worldly: where heroes are common people from specific societies, such as farmers. 
- Religious: inspired by the Bible.

- Funny or satirical: the ones that create laughter.

Moreover we find that there are:

- Concise folk tales

- Detailed folk tales

At the beginning of the $20^{\text {th }}$ century life in Greece starts to radically change and evolve and there is gradual urbanization. The advent of TV, radio and cinema changes the result of people's fantasy. Adventure and our everyday life start to overlap. Moreover school education changes and, as a result, our view of the folk tale and our own attitude toward it changes. While the audience of the folk tales used to be adults, now folk tales are addressed to children. This results in the loss of some folk tale vocabulary.

In Greek folklore studies, people like George loannou and Michael G. Meraklis offered their own interpretation and analysis of Greek folk tales.

George loannou, for example, believed that:

- Everything in the Greek folk tale is vague and indefinite, since time, place and people are non-specific.

- Sometimes, of course, some folk tales have incorporated local traditions, probably because they are related to the topic of the tale or because they help explain how the story evolves, but the folk tale still remains non-specific.

As we have already mentioned, the folk tale begins and ends with stereotypical phrases which point to its vagueness. Each folk tale, as George loannou states, starts from a point of peace or from a fixed point of need and it goes back to the point of peace, which means that the folk tale is circular.

Moreover, the folk tale does not waste time getting into details or providing long descriptions of people and things. The folk tale offers brief descriptions because everything is considered to be already known from the material or mythical reality. That is why the real and the supernatural are linked and intertwine as if this was always the case. The atmosphere of a lot of folk tales reminds us of the Homeric Epics or the Old Testament which take us back to older times when people had deep faith.

The characters in the Greek folk tale are far-stretched, while average and moderate cases are rare, so we find:

- The good person - The villain

- The rich - The poor

- The beautiful - The ugly

George loannou divides the Greek folk tales into:

1. Magical: about incredible adventures and the world of heroes where the laws of physics do not apply.

2. Narrative: for example I kakia pethera (The evil mother-in-law).

3. Religious: about God, Saints, angels and their miracles.

The folk tales were a consolation to Greek people and especially to adults, to whom they were addressed, as we have already mentioned. In earlier times the only form of entertainment for adults in the villages during the cold winter nights were the folk tales that were told around the brick oven of the village. The audience would listen attentively and the storytellers would use a lot of mime to 
enrich their narration since they were living their stories themselves. The places where the tales were told were the bakery, the cobbler's, some people's houses or places near the sea. We must mention that the Turkish people were excellent storytellers. The interaction with them is obvious as the Greek folk tale flourished particularly during the period of Ottoman rule when the conditions of oppression favoured any form of escape such as telling folk tales. From classical antiquity to the Renaissance the folk tales were ignored or not highly regarded. It is only from the $16^{\text {th }}$ century onwards that people become interested in folk tales in Western Europe.

At the beginning of every folk tale the storyteller will say the title of the tale and then the typical phrases such as: "Kokkini klosti demeni stin anemi tyligmeni dos tis klotso na gyrisei, paramythi n'arxinisei" (Red thread wound on a reel, give it a kick to make it turn and start the tale). In ships, after the narrators said the typical phrases, they added: "Kalispera, prymi, plora me ta palikaria ola, kalispera noikokyri, timie karavokyri" (Good afternoon stern, bow, with all the lads, good afternoon our fair captain). In other tales we find the beginning: "Tha sas po ena paramythi, to kouki kai to revithi" (I'll tell you a tale, the fava bean and the chickpea). And after that we find again the common phrase: "Mia for a ki enan kairo" (Once upon a time). At the end the folk tale finishes with the line "Zisan autoi kala ki emeis kalytera" (They lived happily ever after, just like us).

George loannou observes that the episodes of the folk tale circulate easily and they are often adapted and included in many folk tales. This does not mean that there are common grounds. The content of these episodes is not common at all. Moreover in these incredible episodes we find age-old incidents and affairs such as:

- Human sacrifices

- Abductions of women

- People's familiarity with animals which represent age-old social conditions and social beliefs

In the Greek folk tale we will find narrations that come from ancient people, for example about:

- the sun

- the moon

- stars

- dragons

- fairies

- monsters

Michael G. Meraklis, in his turn, observes that the Greek folk tale mythologises reality. In farmers' tales, which are the oldest and simplest tales, we find archaic elements, which can however incorporate new elements. The farmers' tale is the representation of a new social reality with competitive forces:

- rich $\rightarrow$ poor

- clever $\rightarrow$ stupid

- woman $\rightarrow$ man

The farmers' tales include:

- the big landowner's greediness, due to which we end up in conflicts 
- a conciliatory ending, despite all the above conflicts.

The $17^{\text {th }}$ and $18^{\text {th }}$ century folk tales, which are the most extensive ones, reflect the social conflicts of the time. In the $18^{\text {th }}$ and $19^{\text {th }}$ centuries there is social injustice and the folk tales may end in bloodshed and include an expression of sympathy toward the victim.

Russian folklorist Vladimir Propp (1895-1970), a professor of folklore studies at the University of Leningrad who published articles about the myth, introduces us to a different methodology. This scientist decided to focus on a type of texts that no one had studied before. Propp himself did not believe that there is a Big Tale with common cores everywhere, but he believed that the elements spread after the first Big Tale was born. Propp gives us a structural analysis of the folk tale that is essentially a history of the world. His book "Morphology of the tale" had a great impact on international methodology. The main topics of his study are:

- The introduction of the folk tale

- The historical review of the problem

- Methodology

- The function of the characters

- The classification of functions

- The introduction of new characters in the tale.

Propp chooses to scientifically study the category of magical tales. He examines their motifs and makes comparisons. He divides the topics of magical tales according to the parts they consist of and he compares them to his own classification. So Propp adopts a morphological approach and offers us a double categorisation since first there is a description and a classification of magical tales (according to the parts they consist of) and then there is an identification of the connections of these parts to each other and to the whole tale. As Propp himself states, the folk tale has some consistent elements which are either the actions or the feats of the heroes. The sequence of functions is always the same even if some functions are omitted. So the folk tale revolves around one axis only, according to Propp, and all tales belong to one type as regards their structure.

According to Propp again, the introduction of the folk tale includes the description of an initial motionless and peaceful situation which he calls the first, initial function. Propp identifies 31 functions and sub-functions in total, which he lists using alphabet letters. The big parts of the functions are listed in capital letters while their content is listed in small letters:

- $A=$ initial situation

- $B=$ dislocation

- $\quad C=$ interdiction

- $D=$ violation of interdiction

- $E=$ question

- $\mathrm{F}=$ answer to the question

Propp observes that a new character often enters the tale and attacks the hero. This person wants to elicit information from the hero (the good character) 
in order to deceive him and steal something precious the hero has. The villain takes advantage of the whole situation in order to attain his goals. The heart of the tale lies in the negative event that takes place each time and sets the story into motion. At this point the main topic of the folk tale starts. Then the hero (the good person) is forced to leave in order to repair the damage that was done. The hero of the folk tale is therefore the character whose story we read and learn all about his feats. The hero may change, however, during the course of the story.

- A : a negative event takes place and affects a member of the family

- $B$ : the hero leaves to set things right

- C : the hero makes the decision to act when he leaves in order to take revenge for the bad things that happened to his family member (=the plot of the folk tale)

The moment the hero is forced to leave to resolve the problem, a new character often appears, the so-called Donor. The donor helps the hero by giving him or her a magical object. The hero usually needs to accomplish certain feats to obtain this object. It is often difficult to distinguish between the trial and the feats. The moment the hero gets hold of the magical item he or she responds in a particular way to the donor and then moves to the place where the final confrontation will happen. After the hero of the folk tale wins, he or she returns to the point where they started and he or she usually gets married. Marriage is seen as a reward for the hero's deeds. Sometimes, however, another negative event comes to create a new plot twist and the hero is once again forced to leave in order to resolve the matter.

The functions of the folk tale, as Propp mentions, often come in pairs:

- interdiction $\rightarrow$ violation of interdiction

- question $\rightarrow$ answer

Other elements, on the other hand, come in the form of cores, for example the trials which work in the following way:

$\rightarrow$ reaction

$\rightarrow$ reward

A very important part of the folk tale, as Propp states, is the marriage that comes at the end. After a series of difficulties and troubles the hero gets the marriage he or she rightfully deserves. Therefore the marriage is the result of one or more hardships or feats, while a trial results in the hero's obtainment of the precious object.

After Propp, other scientists like sociologists, ethnologists and psychoanalysts took a different approach to the folk tale. Each new grammar and syntax of semiotics helps us analyse the folk tale texts. Scholars like Greimass and the French school wanted to move further than Propp and the 31 functions that he studied, which became a model example for everyone to understand the organizing principles of the folk tale. The new studies focus their attention on the fact that the narrative structure of folk tale is common since the folk tale is universal irrespective of the society in which it was born. There is a common organization of the narration since this is a result of rational thought and logic. The folk tale may be a spontaneous production but its structure must be logical and there will be characters in the story. With this new analysis we are interested in what the 
folk tale intends to say to us, not just what is being narrated. We now have a semantic analysis.

Other scholars like Levy Strauss believe in their turn that the folk tale revolves around two main axes. The first axis is the syntagmatic axis with the characters, the words and the heroes (the hero is always the same) and the other axis is the paradigmatic. Again the functions come in contrastive pairs:

- departure $\neq$ return

- interdiction $\neq$ violation of interdiction

With these scientific approaches we move beyond Propp's 31 functions and we understand that the deep syntagmatic and paradigmatic relations play an organic role that comes to replace the sequence of functions. So we reach the meaning of the folk tale and not just stay at the narrative part.

The hero of the folk tale tries to accomplish a feat to persuade us that he or she deserves the title of the hero. As long as the heroes act, they will prove their role. In case the hero does not make it, then he or she will need to go through a new trial (perform a new feat) in order to reach the level of the so-called hero. The action of the folk tale starts with these trials. In a lot of folk tales there is also a mediation of a third person who helps the hero accomplish his or her mission and be recognized as a hero.

Every folk tale is therefore the story of a life that is exemplary, with a hero who performs good deeds and then asks for recognition from the "other". With objective evaluation we receive, as well as the hero receives, moral commendation. So we understand that the folk tale and its narrative help us reach the meaning of human life. Each narrative with its structure leads us to the point of explaining human life.

And if we read the feats of the hero in reverse order we notice that there are logical prerequisites. Every hero has qualities such as:

- Upbringing, which allows the hero to accomplish heroic feats.

Looking at an example such as "Sleeping beauty" we notice that:

1. The parents want to protect their child after the fairies cursed her (there is nothing heroic up to this point). So, there is a narrative form through which we understand that when God gives orders, a human being obeys, because God is omnipotent. The ideology of the folk tale is the idea of obeying a superior force. In a fixed situation like the one we described, a person can:

- Say no and revolt

- Or try to avoid the situation that arises

- Or obey and follow the eternal pattern of human obedience

2. Then the Prince comes and finds the Sleeping Princess. Due to his upbringing the Prince knew from the start how to hunt and not be afraid. He possessed social assuredness. He therefore appears as a model to other people and of course the "future hero" must have the basic requirements to be able to act. It is only when he acts and is recognized by other people that he becomes the hero.

So we realise that there may be a first level of narration but beneath this level there are deeper thoughts which lead us to a philosophical idea. People have always looked for an answer to the eternal question "Who am I?" The hero 
is presented as a decal where the audience of the folk tale finds ways of answering this question. So the hero becomes a model where the meaning of life itself is defined.

The folk tale gives us the image of a person that is a model, either negative or positive. After his or her initiation, this person becomes worthy of a reward and recognition from other people. This raises him or her to a moral level and this person becomes a model on a moral level, a model that other people are interested in.

Of course all these explorations of the meaning of life depend on people's ideology and moral values. These values do not remain fixed and unchanging. So there are two basic differentiations:

- From one country to the other country

- From one era to the next

Together with the hero we have the villain, the anti-hero. He or she has the same capacities and the same behaviour. These two models have the same strength. This division into two usually comes at the beginning of the folk tale. At some point the two parallel paths cross and then the so-called confrontation of the two characters takes place and one of the two wins. The winner is the one who has positive moral values. The point of confrontation between the hero and the villain is the axis, the engine that drives the narrative forward. From that point on, everything changes in the folk tale. In order for the folk tale to take this turn, the hero is usually given a precious object that is valuable as long as its owner wishes it to be valuable. Then the owner becomes the actor of the narrative and automatically the hero. The owner of the precious object is now the "actor" who becomes the strongest character, most capable of bringing changes. The centre of the narrative unit is the final goal: "Ezisan autoi kala ki emeis kalytera" (They lived happily ever after, just like us). The hero, however, is not just a simple agent of an action and of course the hero has a past that helps him or her.

And while at the beginning of the folk tale there is a contextual ideology, at the end this ideology is different, enriched by the new experiences. Every human action makes sense when it is expressed in a world of ideas. The hero and the anti-hero are connected. They are the good and the bad side of the same person. The Trial helps bring the good qualities of the hero to the surface. Every idea that leads to an action must be placed within a social context. The hero and the villain do the same things, the one in a positive way and the other in a negative way. The hero, the anti-hero and the Donor are the three characters who are the main actors of the folk tale. So we watch the evolution of the same person:

- At the beginning he or she is motionless.

- Then he or she confronts his or her own evil self and decides to take action.

- Then he or she becomes a hero and a model

Of course there needs to be a superior force such as:

- Magicians

- Fairies

- Mother's soul after death

The Donor in his or her turn is a supernatural person, a superhuman who 
acts or who sometimes simply watches the course of events from far away. The donor is given his or her power by the people who create and give shape to a person. In this way the heroes become heroes and guardians of values. These moral values belong to the social circle where the folk tale is told. Around the middle of the folk tale the Donor appears and he or she evolves during the course of the story depending on the social context. Sometimes the Donor disappears. So the Donor is closely related to the people who create him or her, while the hero, in turn, is a mirror of people as a whole. We realise that there is human faith in this supernatural force, in the Supreme Being, and in infinity.

\section{Conclusion}

With the analysis of the Greek folk tale we come to realise that Greek folk tales are a source of inspiration and study for scientists, but also for teachers who can use them at all educational levels, from kindergarten to university. And if we accept the view that nothing else can express the idiosyncrasy of a nation as accurately as its folk tales, then we come to the conclusion that the Greek folk tale, apart from its anthropological depth and its significance as an object of study in folkloristics and in philology, is itself a credible witness to the true Greek character.

\section{Bibliography}

Braudel F. Ecrits sur l'histoire. Paris, 1969. 250 p.

Herzfeld M. Ours Once More: Folklore, Ideology and the Making of Modern Greece. New York: Pella Publishing Company, 1986. 300 p.

Greek mythology. - [Electronic resource]. - Mode of access: https://www.britannica.com/ topic/Greek-mythology

Kyriakidou-Netsoros A. The Theory of Greek Folklore. Critical Analysis. Athens: Society for Neohellenic Cultural and Educational Studies, 1978. 260 p.

\section{References}

Braudel, F. (1969). Ecrits sur l'histoire. Paris.

Herzfeld, M. (1986). Ours Once More: Folklore, Ideology and the Making of Modern Greece. New York: Pella Publishing Company

Greek mythology. - [Electronic resource]. - Mode of access: https://www.britannica.com/ topic/Greek-mythology

Kyriakidou-Netsoros, A. (1978). The Theory of Greek Folklore. Critical Analysis. Athens: Society for Neohellenic Cultural and Educational Studies

Стаття надійшла до редакції 14.02.2019 року. 